\title{
Using the RNA synthetic activity of glutamate dehydrogenase to illuminate the natural role of the enzyme
}

\author{
Godson O. Osuji ${ }^{*}$, Wenceslaus C. Madu ${ }^{\#}$ \\ CARC, Prairie View A \& M University, Prairie View, USA \\ Email:"goosuji@pvamu.edu, cropyielddoublingbiotechnology@yahoo.com
}

Received 29 August 2012; revised 29 September 2012; accepted 9 October 2012

\section{ABSTRACT}

Glutamate Dehydrogenase (GDH; EC 1.4.1.2) catalyzes the reversible amination of $\alpha$-ketoglutarate to glutamate, and the polymerization of nucleoside triphosphate(s) to RNA. But the natural role of the reversible amination reaction is the subject of an expanding conversation. The aim was to illuminate the natural role of GDH through its RNA synthetic activity. Stoichiometric combinations of mineral salts that targeted the GDH subunit compositions were applied to field-cultivated peanuts. GDH of seeds were made to synthesize RNA in the deamination and then in the amination direction. Free amino acids were analyzed by HPLC. Glutamate synthase (GOGAT) was assayed by photometry. Free amino acid yields increased from the control's lowest $\left(9.8 \mathrm{~kg} \cdot \mathrm{ha}^{-1}\right)$ and amination-deamination ratio $(0.05)$ through 12.0 - 23.0 $\mathbf{k g} \cdot \mathbf{h a}^{-1}$ in the $\mathbf{K}-, \mathbf{N}+\mathbf{K}+\mathbf{P}+\mathrm{S}-$, Pi-, $\mathbf{N}+\mathrm{S}-$, S-treated peanuts with amination-deamination ratios between 0.6 and 10.0 until at the $P+K$-treated peanut which had the highest amino acid yield $\left(52.4 \mathrm{~kg} \cdot \mathrm{ha}^{-1}\right)$ and the highest amination-deamination ratio (61). The $\mathrm{Km}$ and Vmax values of GOGAT were within the normal range. Yields of free amino acids resulting from GDH aminating activity increased from $<\mathbf{1 . 0}$ $\mathrm{kg} \cdot \mathrm{ha}^{-1}$ in the control, through 2.2 in the $\mathrm{N}+\mathrm{S}-, 6.84$ in the $\mathrm{P}+\mathrm{N}-, 17.3$ in the $\mathrm{N}$-, to $42.6 \mathrm{~kg} \cdot \mathrm{ha}^{-1}$ in the $\mathrm{P}+\mathrm{K}-$ treated peanut. These results show that the natural role of the GDH amination activity is to assimilate escalating multiples of the quantities of $\mathrm{NH}_{4}^{+}$ion as assimilated via the GS-GOGAT pathway. Peanut protein yields increased in parallel with GDH aminating activities and free amino acid yields such that the control peanut had the lowest protein $\left(<26.0 \mathrm{~kg} \cdot \mathrm{ha}^{-1}\right)$ and the yields increased exponentially (500 - 600 $\mathrm{kg} \cdot \mathrm{ha}^{-1}$ ) through the $\mathrm{K}-, \mathrm{P}+\mathrm{S}-, \mathrm{Pi}-, \mathrm{N}$-treated to 910 $\mathrm{kg} \cdot \mathrm{ha}^{-1}$ in the $\mathrm{P}+\mathrm{K}$-treated peanut with the highest aminating activity of GDH. The ability of GDH ami-

\footnotetext{
*Corresponding author.

"Current Address: Imo State Polytechnic, Umuagwo, PMB 1472, Owerri, Imo State, Nigeria.
}

nating activity to escalate protein yields of food crops could be employed to address protein-energy malnutrition syndrome of developing nations.

Keywords: Peanut; Stoichiometric Mineral Salt Combinations; GDH Amination-Deamination Ratio; Glutamate Synthase; Amino Acid and Protein Yields $\mathrm{ha}^{-1}$

\section{INTRODUCTION}

Glutamate Dehydrogenase (GDH; EC 1.4.1.2) is an oxidoreductase that catalyzes the reversible reductive amination of $\alpha$-ketoglutarate $(\alpha-\mathrm{KG})$ in the synthesis of glutamate. It also polymerizes nucleoside triphosphate(s) in the absence of template to produce RNA [1]. GDH is ubiquitous in all plants studied. Although the biochemical mechanisms of the oxidoreductase reaction have been studied in detail, and the function of the RNA is increasingly unfolding, the natural role of the reversible amination of $\alpha-\mathrm{KG}$ is the subject of an expanding conversation [2-5]. The discovery of the glutamate synthase (GOGAT; EC 1.4.1.13), and glutamine synthetase (GS; EC6.3.1.2) cycle [6] with $\mu \mathrm{M} \mathrm{Km}$ and $\mu$ moles $\cdot \mathrm{min}^{-1}$ Vmax values for $\mathrm{NH}_{4}^{+}$ion compared with mM Km and mmoles $\cdot \min ^{-1} \mathrm{Vmax}$ values of GDH were interpreted to suggest that the GS-GOGAT cycle might be the only mechanism for $\mathrm{NH}_{4}^{+}$ion assimilation and glutamate synthesis, while GDH might function in the deamination of glutamate [7]. But the $\mathrm{Km}$ value for the assimilation of $\mathrm{NH}_{4}^{+}$ion by GDH has been demonstrated to be in the upper $\mu \mathrm{M}$ range and within the $\mathrm{NH}_{4}^{+}$ion concentrations of the mitochondria $[5,8]$. The aim of this project was to illuminate the natural role of $\mathrm{GDH}$ through its RNA synthetic activity. Computer interpretation of $\mathrm{NH}_{4}^{+}$ion and amino acid metabolism did not illuminate the biological role of the enzyme [9]. Some of the conversations also surround the inability to estimate the products of the oxidoreductase reaction over all the encompassing range of environmental conditions for plant growth. Some of the experimentations that have 
projected the GDH deamination role employed plant specimens that were subjected to carbon nutrient starvation, deprivation of photosynthesis, and/or of essential mineral nutrients $[2,7]$. The approach of the research project reported hereunder was different being environmentally broad in scope, and based on the analyses of mature seeds harvested from plants cultivated and fertilized under normal field plot conditions. Also, instead of analyzing $\mathrm{NH}_{4}^{+}$ion, glutamate, and $\mathrm{NADH}$ products of the reversible oxidoreductase reaction, the RNA products synthesized by the enzyme were analyzed. GDH has been synthesizing RNA since evolutionary time [10], the RNA functioning to permute and normalize the metabolic pathways at the mRNA level in response to wide variations of soil mineral ion concentrations.

Since GDH is a very important enzyme in plant carbon and nitrogen metabolism [2-5,7-10], its natural role may correlate positively with increases in protein, fatty acid, and carbohydrate yields. There is need to double and exponentially increase crop protein yields per unit area of land in order to minimize protein-energy malnutrition syndrome of developing countries. Could the natural role of GDH be associated with food crop yield doubling biotechnology? Peanut was chosen for this project because it is whole food/feed rich in proteins, fatty acids, carbohydrate etc, and consumed world-wide with considerable contribution to global economy; and its GDH is very active in RNA synthesis [11-13].

\section{MATERIALS AND METHODS}

Treatment of peanuts with mineral salt solutions: Peanut (Arachis hypogaea L. Cv. Virginia) seeds were planted in boxes $243.84 \times 243.84 \times 30.48 \mathrm{~cm}$ (width $\times$ length $\times$ depth) in the field plot, each box filled with Metro Mix 700 peat moss as described before [12]. About $100-110$ seeds were planted per box. The applied mineral salt compositions mimicked and targeted the binomial subunit polypeptide compositions of the GDH isoenzymes [13]. The first box was left as the untreated control; the second box $(\mathrm{N})$ was treated with $1 \mathrm{~L}$ of $\mathrm{NH}_{4} \mathrm{Cl}$ solution $(25 \mathrm{mM})$, the third box $(\mathrm{Pi})$ was treated with $1 \mathrm{~L}$ of $\mathrm{Na}_{2} \mathrm{HPO}_{4}$ solution $(20 \mathrm{mM})$; the fourth box (S) was treated with $1 \mathrm{~L}$ of $\mathrm{Na}_{2} \mathrm{SO}_{4}$ solution $(50 \mathrm{mM})$; the fifth box $(\mathrm{K})$ was treated with $1 \mathrm{~L} \mathrm{KCl}$ solution $(4 \mathrm{mM})$; the sixth box $(\mathrm{N}+\mathrm{P}+\mathrm{K}+\mathrm{S})$ positive control was treated with $1 \mathrm{~L}$ of combined $\mathrm{NH}_{4} \mathrm{Cl}(25 \mathrm{mM}), \mathrm{Na}_{2} \mathrm{HPO}_{4}(20$ $\mathrm{mM}), \mathrm{Na}_{2} \mathrm{SO}_{4}(50 \mathrm{mM})$, and $\mathrm{KCl}(4 \mathrm{mM})$ solution; the seventh box $(\mathrm{P}+\mathrm{K})$ was treated with $1 \mathrm{~L}$ of combined $\mathrm{Na}_{2} \mathrm{HPO}_{4}(20 \mathrm{mM})$ and $\mathrm{KCl}(4 \mathrm{mM})$ solution; the eighth box $(\mathrm{N}+\mathrm{S})$ was treated with $1 \mathrm{~L}$ of combined $\mathrm{NH}_{4} \mathrm{Cl}(25$ $\mathrm{mM})$ and $\mathrm{Na}_{2} \mathrm{SO}_{4}(50 \mathrm{mM})$ solution; the ninth box $(\mathrm{P}+\mathrm{N})$ was treated with $1 \mathrm{~L}$ of combined $\mathrm{Na}_{2} \mathrm{HPO}_{4}(20 \mathrm{mM})$ and $\mathrm{NH}_{4} \mathrm{Cl}(25 \mathrm{mM})$ solution; the tenth box $(\mathrm{P}+\mathrm{S})$ was treated with $1 \mathrm{~L}$ of combined $\mathrm{Na}_{2} \mathrm{HPO}_{4}(20 \mathrm{mM})$ and
$\mathrm{Na}_{2} \mathrm{SO}_{4}(50 \mathrm{mM})$ solution as described before [12]. The boxes were watered every other day. Mineral salt solutions were applied sequentially, first at pre-flowering stage ( 2 weeks after seed germination), second at flowering, and third at post-flowering. When the leaves turned yellow (peanut maturity), pods and shoots were harvested, allowed to dry on the greenhouse floor for about 2 weeks, and weighed. Pods were shelled by hand, and the kernels (seeds) weighed. Seeds were stored at $-30^{\circ} \mathrm{C}$.

Purification and assay of GDH: GDH charge isomers were extracted from peanut seeds that were harvested from the control or mineral-treated boxes, and purified by electrophoresis as described before [11]. RNA synthetic activities of GDH isoenzymes were assayed in the deamination and amination directions in separate tubes.

For demonstrating the arrays of RNA synthesized by GDH in the amination direction, the substrate solutions were prepared in $0.1 \mathrm{M}$ Tris-HCl buffer $(\mathrm{pH} 8.0)$ containing the four NTPs $(0.6 \mathrm{mM}$ each $), \mathrm{CaCl}_{2}(3.5 \mathrm{mM})$, $\mathrm{NH}_{4} \mathrm{Cl}(0.875 \mathrm{mM}), \alpha-\mathrm{KG}(10.0 \mathrm{mM}), \mathrm{NADH}(0.225$ $\mathrm{mM}), 5$ Units RNase inhibitor, 1 Unit DNase 1, and $5 \mu \mathrm{g}$ of actinomycin D as described before [12]. Reaction was started by adding $0.2 \mathrm{~mL}$ of GDH charge isomers eluted per chamber of whole-gel eluter. The eluted GDH contained $3-9 \mu \mathrm{g}$ protein per $\mathrm{mL}$. Final volume of the reaction was brought to $0.4 \mathrm{~mL}$ with $0.1 \mathrm{M}$ Tris- $\mathrm{HCl}$ buffer $\mathrm{pH}$ 8.0. In the deamination direction, the substrate solutions were prepared in $0.1 \mathrm{M}$ Tris- $\mathrm{HCl}$ buffer $(\mathrm{pH}$ 8.6) containing the four NTPs ( $0.6 \mathrm{mM}$ each), $\mathrm{CaCl}_{2}$ (3.5 $\mathrm{mM})$, L-glu $(3.23 \mu \mathrm{M}), \mathrm{NAD}^{+}(0.375 \mu \mathrm{M}), 5$ Units RNase inhibitor, 1 Unit DNase 1, and $5 \mu \mathrm{g}$ of actinomycin $\mathrm{D}$ as described before [11]. Reaction was started by adding $0.2 \mathrm{~mL}$ of GDH charge isomers eluted per chamber of the whole-gel eluter. The eluted GDH contained $3-9 \mu \mathrm{g}$ protein per $\mathrm{mL}$. Final volume of the reaction was brought to $0.4 \mathrm{~mL}$ with $0.1 \mathrm{M}$ Tris-HCl buffer $\mathrm{pH}$ 8.6. Reactions were incubated at $16^{\circ} \mathrm{C}$ for $3 \mathrm{~h}$ and stopped by phenol-chloroform (pH 5.5) extraction of the enzyme. RNA was precipitated with ethanol, and dissolved in minimum volume of molecular biology quality water. RNA yield and quality were determined by agarose gel electrophoresis, and photometry. Assays were carried out in duplicate to verify the reproducibility of the results.

For determination of the yield of the product RNA in the amination direction, the substrate solutions were prepared in $0.1 \mathrm{M}$ Tris- $\mathrm{HCl}$ buffer $(\mathrm{pH} 8.0)$ containing the four NTPs $(0.6 \mathrm{mM}$ each $), \mathrm{CaCl}_{2}(3.5 \mathrm{mM}), \mathrm{NH}_{4} \mathrm{Cl}$ $(0.875 \mathrm{mM}), \alpha$-KG $(10.0 \mathrm{mM}), \mathrm{NADH}(0.225 \mathrm{mM}), 5$ Units RNase inhibitor, 1 Unit DNase 1 , and $5 \mu \mathrm{g}$ of actinomycin $\mathrm{D}$ as described above. Reaction was started by adding $0.2 \mathrm{~mL}$ of the pooled GDH charge isomers eluted in all the chambers of the whole-gel eluter. Final volume of the reaction was brought to $0.4 \mathrm{~mL}$ with $0.1 \mathrm{M}$ 
Tris- $\mathrm{HCl}$ buffer $\mathrm{pH}$ 8.0. In the deamination direction, the substrate solutions were prepared in $0.1 \mathrm{M}$ Tris- $\mathrm{HCl}$ buffer ( $\mathrm{pH} 8.6)$ containing the four NTPs (0.6 mM each), $\mathrm{CaCl}_{2}$ (3.5 mM), L-glu (3.23 $\left.\mu \mathrm{M}\right), \mathrm{NAD}^{+}(0.375 \mu \mathrm{M}), 5$ Units RNase inhibitor, 1 Unit DNase 1 , and $5 \mu \mathrm{g}$ of actinomycin $\mathrm{D}$ as described above. Reaction was started by adding $0.2 \mathrm{~mL}$ of the pooled GDH charge isomers eluted in all the chambers of the whole-gel eluter. Final volume of the reaction was brought to $0.4 \mathrm{~mL}$ with $0.1 \mathrm{M}$ Tris- $\mathrm{HCl}$ buffer $\mathrm{pH}$ 8.6. Reactions were incubated at $16^{\circ} \mathrm{C}$ for $3 \mathrm{~h}$ and stopped by phenol-chloroform 5:1 (pH 5.5) extraction of the enzyme. RNA was precipitated with ethanol, dissolved in $100 \mu \mathrm{L}$ of molecular biology quality water, and chromatographed through Zymoclean Gel RNA spin column (Zymo Research, CA, USA). RNA yield was determined by photometry (NanoDrop spectrophotometer). Assays were repeated three times with different elutions of GDH, and the average RNA yields were calculated.

Extraction and assay of GOGAT: Glutamate synthase (EC 1.4.1.13) was extracted from $50 \mathrm{~g}$ of peanut seed by homogenizing with $100 \mathrm{~mL}$ of ice-cold $0.1 \mathrm{M}$ potassium phosphate buffer ( $\mathrm{pH} \mathrm{8)}$ containing $0.1 \mathrm{M} \mathrm{KCl}, 0.1 \%$ (v/v) Triton X-100, and $14 \mathrm{mM}$ 2-mercaptoethanol [14], and partially purified as described before [15]. The activity was assayed by photometry within $\alpha-\mathrm{KG}$ concentration range of $0.3-33.3 \mathrm{mM}$, and L-glutamine range of $0.3-66 \mathrm{mM}$. The concentration of NADH was fixed at $0.1 \mathrm{mM}$ as described before [15]. Assays were repeated three times and the average was applied to calculate the activities as mmoles of NADH oxidized per minute per mg protein. Double reciprocal plots were constructed with the activities derived. Protein content was determined with the Folin-Ciocalteau reagent using lysozyme as the standard.

Proximate analyses: Free amino acids were custom extracted from peanut seeds and custom analyzed (UBE Analytical Laboratories, California, USA) by HPLC. Acid detergent fiber and total protein contents of peanut seeds were custom analyzed (Universal Testing, Illinois, USA) by standard gravimetry.

\section{RESULTS}

Stoichiometric combinations of mineral salts mimicking the GDH isoenzyme ratios: The stoichiometric combinations of mineral salts (Table 1) mimicked the binomial subunit assembly and distribution of the GDH isoenzymes. Furthermore, to target the GDH subunits directly, the stoichiometric combinations of mineral salts (Table 1) were applied at the $\mu \mathrm{M}$ instead of the $\mathrm{M}$ level typical of inorganic fertilizers; and at two or more times in the life of the crop so that at all times the GDH subunit compositions did not fluctuate widely. In addition to the $\mathrm{NH}_{4}^{+}, \mathrm{PO}_{4}^{3-}, \mathrm{K}^{+}$, and $\mathrm{SO}_{4}^{2-}(\mathrm{N}, \mathrm{Pi}, \mathrm{K}, \mathrm{S})$ added, there were trace micronutrients $\left(\mathrm{Ca}^{2+}\right.$, Borate, $\mathrm{Mg}^{2+}, \mathrm{Mn}^{2+}$, $\mathrm{Fe}^{3+}$, and Silicate) in the peat moss. GDH is composed of three subunit polypeptides assembled binomially in hexameric molecules to give 28 isoenzymes [16]. The stoichiometric combinations (Table 1) made for internal repeats in the treatments thus limiting stochastic variability in the treatments, imposed firm control on the number of experimental repeats, and consolidated the biochemical comprehensiveness of the project design. The growth conditions made for unrestricted photosynthesis, water supply, and environment-wide supply of mineral salts.

GDH isomerization in response to the mineral ions: The full complement of the GDH isoenzymes was present in the control peanut. But the anionic isoenzymes declined quickly with increasing electromagnetic activity of the mineral ions until at the $\mathrm{P}+\mathrm{S}-, \mathrm{Pi}-, \mathrm{P}+\mathrm{N}-$, and $\mathrm{P}+\mathrm{K}$-treated peanuts when the cationic GDH isoenzymes were predominant [12]. There have been suggestions that the anionic isoenzymes of GDH are deaminating [17]. Therefore, the stoichiometric mineral ion combinations produced diverse environment-wide biochemical conditions that induced the full spectrum of the isomerization of GDH. The biochemical design of the project was thus comprehensive. This was important for the balanced judgment of the free amino acids, protein, and cellulose yields in relation to the GDH deamination and amination activities.

The peanut growth conditions induced and synchro-

Table 1. Stoichiometric combinations of mineral nutrients.

\begin{tabular}{ccccc}
\hline$\downarrow$ Treatments $\rightarrow$ & $\mathrm{N}(25 \mathrm{mM})$ & $\mathrm{S}(50 \mathrm{mM})$ & $\mathrm{K}(4 \mathrm{mM})$ & $\mathrm{P}(20 \mathrm{mM})$ \\
\hline $20 \mathrm{mM} \mathrm{Na}_{2} \mathrm{PO}_{4}$ & $\mathrm{P}+\mathrm{N}$ & $\mathrm{P}+\mathrm{S}$ & $\mathrm{P}+\mathrm{K}$ & $\mathrm{P}+\mathrm{P}$ \\
$4 \mathrm{mM} \mathrm{KCl}$ & $\mathrm{K}+\mathrm{N}$ & $\mathrm{K}+\mathrm{S}$ & $\mathrm{K}+\mathrm{K}$ & \\
$25 \mathrm{mM} \mathrm{Na}_{2} \mathrm{SO}_{4}$ & $\mathrm{~N}+\mathrm{S}$ & $\mathrm{S}+\mathrm{S}$ & & \\
$25 \mathrm{mM} \mathrm{NH}_{4} \mathrm{Cl}$ & $\mathrm{N}+\mathrm{N}$ & & & \\
\hline
\end{tabular}

Mineral treatments: $\mathbf{N}$ was $1 \mathrm{~L}$ of $25 \mathrm{mM} \mathrm{NH}_{4} \mathrm{Cl}$. $\mathbf{S}$ was $1 \mathrm{~L}$ of $50 \mathrm{mM} \mathrm{Na} \mathrm{SO}_{4}$. $\mathbf{K}$ was $1 \mathrm{~L}$ of $4 \mathrm{mM} \mathrm{KCl}$. Pi was $1 \mathrm{~L}$ of $20 \mathrm{mM}$ $\mathrm{Na}_{2} \mathrm{HPO}_{4}$. $\mathbf{P}+\mathbf{N}$ was $1 \mathrm{~L}$ of combined $20 \mathrm{mM} \mathrm{Na}_{2} \mathrm{HPO}_{4}$ and $25 \mathrm{~m} \mathrm{NH}_{4} \mathrm{Cl}$. $\mathbf{P}+\mathbf{S}$ was $1 \mathrm{~L}$ of combined $20 \mathrm{mM} \mathrm{Na}_{2} \mathrm{HPO}_{4}$ and $50 \mathrm{mM}$ $\mathrm{Na}_{2} \mathrm{SO}_{4}$. $\mathbf{P}+\mathbf{K}$ was $1 \mathrm{~L}$ of combined $20 \mathrm{mM} \mathrm{Na} 2 \mathrm{HPO}_{4}$ and $4 \mathrm{mM} \mathrm{KCl}$. $\mathbf{N}+\mathbf{S}$ was $1 \mathrm{~L}$ of combined $25 \mathrm{mM} \mathrm{NH}_{4} \mathrm{Cl}$ and $50 \mathrm{mM}$ $\mathrm{Na}_{2} \mathrm{SO}_{4}$. 
nized the isomerization of the GDH and synthesis of RNA by the GDH [12]. GDH isomerization and synthesis of RNA as the target sites of mineral salt action are due to the binomial distribution of its three subunits in the hexameric isoenzymes, on the basis of the twin nonallelic $\mathrm{GDH}_{1}$ and $\mathrm{GDH}_{2}$ gene structure, with the gene $\left(\mathrm{GDH}_{1}\right)$ encoding the more acidic subunits $(\mathrm{a}$, and $\alpha)$ being heterozygous and co-dominant, whereas the other gene $\left(\mathrm{GDH}_{2}\right)$ encoding the less acidic subunit $(\beta)$ is homozygous [18].

Deaminating and aminating activities of GDH: RNA synthesis by GDH in the deamination direction (Figure 1) shows that the GDHs of several of the treated peanuts were active in the deamination direction. The deaminating activities of the GDH of $\mathrm{N}+\mathrm{P}+\mathrm{K}+\mathrm{S}$ - (Figure 1(b)), $\mathrm{NH}_{4} \mathrm{Cl}$ - (similar to Figure 1(b)), $\mathrm{P}+\mathrm{N}$-treated (Figure 1(d)) peanuts were characterized by high molecular weight RNAs $(>10 \mathrm{~kb})$ synthesized by GDH. The low deaminating activities of the GDH of $\mathrm{P}+\mathrm{K}$ - (Figure 1(f)), and K-treated (similar to Figure 1(f)) peanuts were

\section{Whole Gel Elution Chambers}

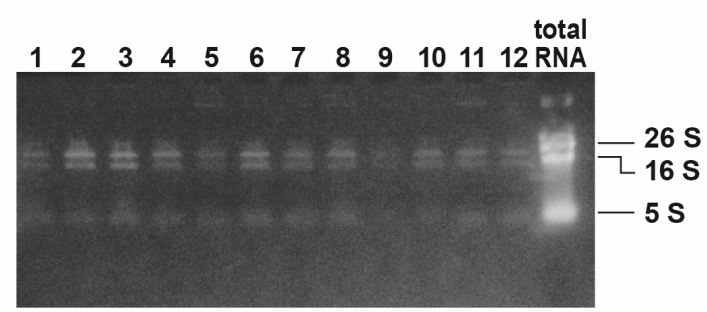

(a) Control Peanut

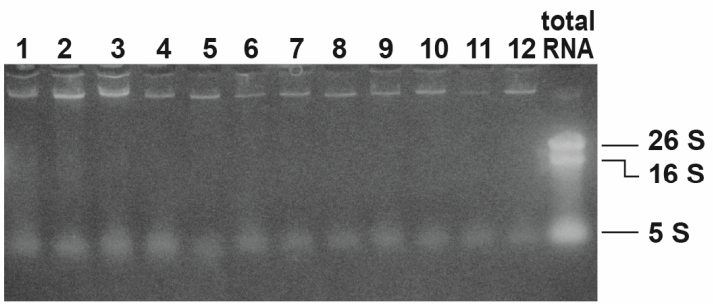

(b) NPKS-treated Peanut

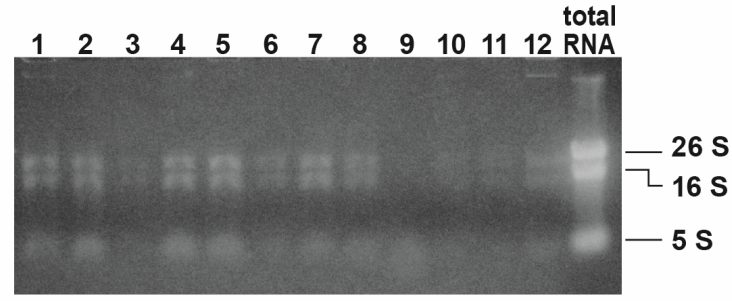

(c) Pi-treated Peanut characterized by low molecular weights ( $\sim 100$ bases long) of GDH-synthesized RNAs. RNA synthesis by GDH in the amination direction (Figure 2) showed that the GDHs of several of the treated peanuts were also active in the amination direction. The low aminating activities of the GDH of control (Figure 2(a)), and P+S-treated (Figure 2(b)) peanuts were characterized by low molecular weights ( $\sim 100$ bases long) of GDH-synthesized RNAs. Similarly, the high aminating activities of the GDH of Pi- (Figure 2(d)), P+N- (Figure 2(e)), and P + K-treated (Figure 2(h)) peanuts were characterized by high molecular weight RNAs (>10 kb) synthesized by the enzyme. The deamination and amination product RNAs (Figures 1 and 2) confirmed that the stoichiometric mineral ion treatments induced the full spectrum of isomerization of peanut GDH and differentiated deamination from the amination activity.

Amination-Deamination ratio of GDH: Figures 1 and 2 visually demonstrated the differentiation of the deaminating from the aminating activities of GDH by the

\section{Whole Gel Elution Chambers}

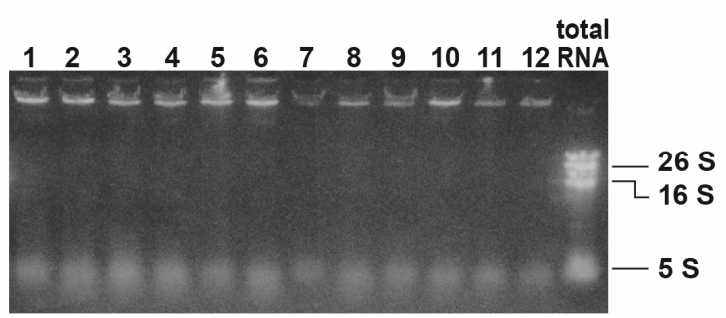

(d) PN-treated Peanut

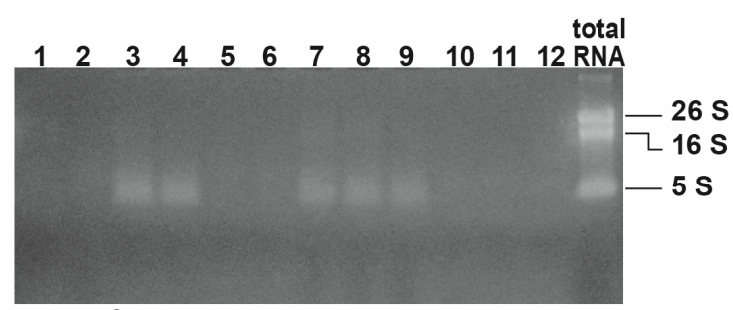

(e) $\mathrm{SO}_{4}^{-2}$-treated Peanut

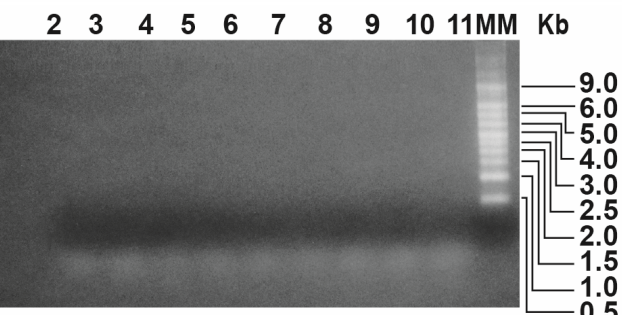

(f) PK-treated Peanut

Figure 1. Deamination activity of peanut GDH: RNA arrays synthesized by whole gel-purified GDH isoenzymes of the

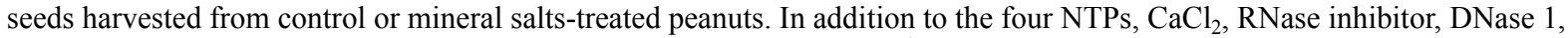
and actinomycin $\mathrm{D}$, the deamination reaction cocktail contained $\mathrm{NAD}^{+}(0.375 \mu \mathrm{M})$, glutamate $(3.23 \mu \mathrm{M})$ and $0.2 \mathrm{~mL}$ of $\mathrm{GDH}$ isoenzymes eluted per chamber of the whole-gel eluter. Reactions were incubated at $16^{\circ} \mathrm{C}$ for $3 \mathrm{~h}$, stopped by phenol-chloroform ( $\mathrm{pH} 5.5$ ) extraction of the enzyme, and product RNA was precipitated with ethanol. RNAs were electrophoresed on $2 \%$ agarose gels. The RNA profiles per treated peanut were reproducible in replicate agarose gels. MM is RNA molecular weight marker; total RNA marker was isolated from corresponding peanut seeds by the method of [38]. 
Whole Gel Elution Chambers

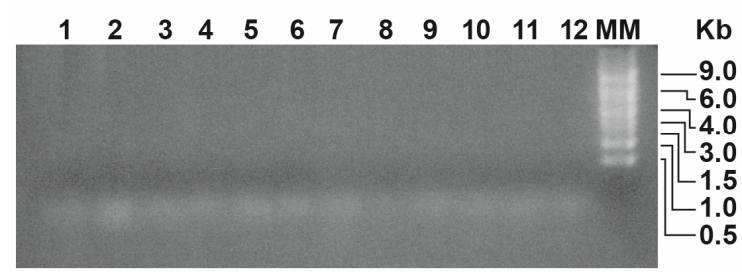

(a) Control Peanut

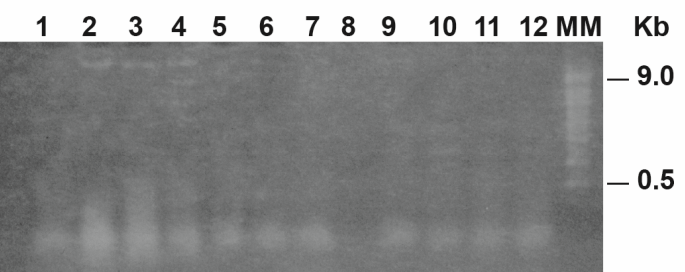

(b) PS-treated Peanut

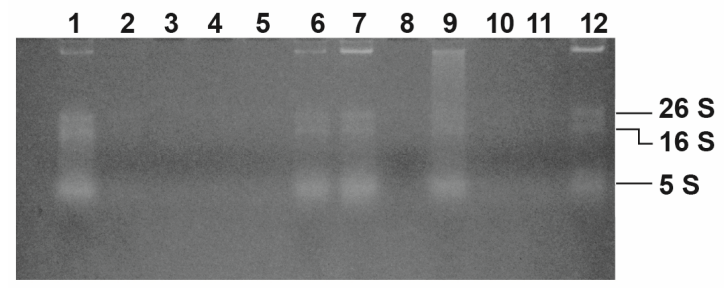

(c) $\mathrm{NH}_{4} \mathrm{Cl}$-treated Peanut

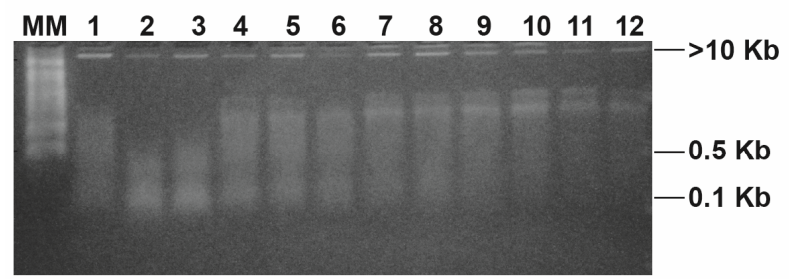

(d) Pi-treated Peanut
Whole Gel Elution Chambers

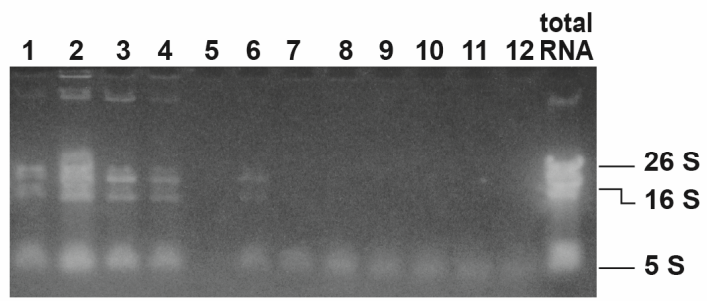

(e) PN-treated Peanut

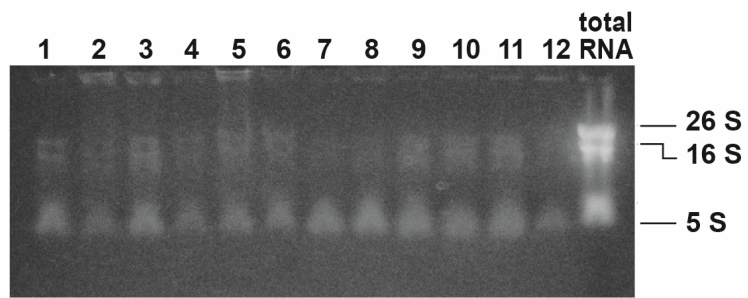

(f) NPKS-treated Peanut

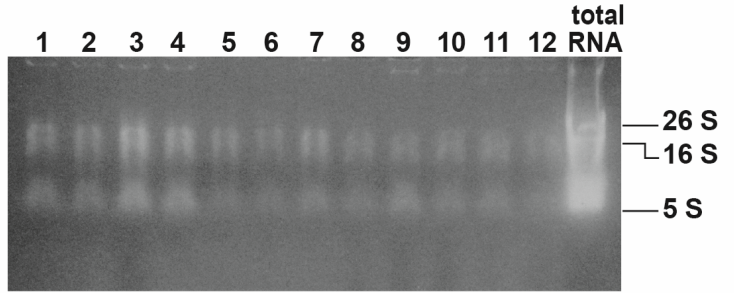

(g) NS-treated Peanut

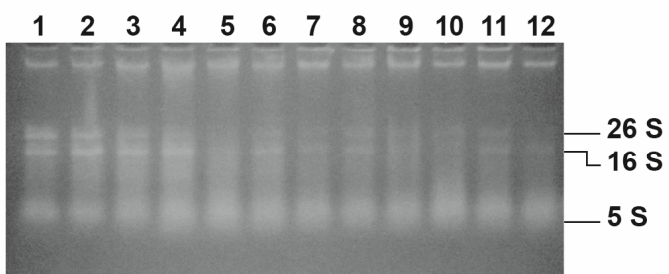

(h) PK-treated Peanut

Figure 2. Amination activity of peanut GDH: RNA arrays synthesized by whole gel-purified GDH isoenzymes of the seeds harvested from control or mineral salts-treated peanuts. In addition to the four NTPs, $\mathrm{CaCl}_{2}$, RNase inhibitor, DNase 1, and actinomycin $\mathrm{D}$ the amination reaction cocktail contained $\mathrm{NH}_{4} \mathrm{Cl}(0.875 \mathrm{mM}), \alpha-\mathrm{KG}(10.0 \mathrm{mM}), \mathrm{NADH}(0.225 \mathrm{mM})$, and $0.2 \mathrm{~mL}$ of GDH isoenzymes eluted per chamber of whole-gel eluter. Reactions were incubated at $16^{\circ} \mathrm{C}$ for $3 \mathrm{~h}$, stopped by phenol-chloroform ( $\mathrm{pH}$ 5.5) extraction of the enzyme, product RNA was precipitated with ethanol. RNAs were electrophoresed on $2 \%$ agarose gels. The RNA profiles per treated peanut were reproducible in replicate agarose gels. MM is RNA molecular weight marker; total RNA marker was isolated from corresponding peanut seeds by the method of [38].

stoichiometric mineral salt combinations. The aminating capacity (amination-deamination ratio) varied widely. Compared with the control, treatment of the peanut with $\mathrm{P}+\mathrm{K}$ increased the aminating capacity by $>1000$ folds (Table 2) thus showing that the stoichiometric mineral ions functioned to displace the equilibrium position of the GDH oxidoreductase activity. This permitted the aminating activity to function with minimal interference from the deaminating activity and vice versa per hexameric GDH molecule and per landscape of crop. Also, yields of the GDH-synthesized RNAs per treated crop
(Table 2) showed that whereas the amination activity rose up to $\sim 40 \mu \mathrm{g}$ RNA $\mu \mathrm{g}^{-1} \mathrm{GDH}$, the deamination activity was limited to a lower maximum of $\sim 19 \mu \mathrm{g}$ RNA $\mu^{-1}$ GDH. Therefore, the peanut GDH was much more active in the amination than in the deamination direction. Yields of product RNAs in the two reaction directions were not always reciprocally related thus further suggesting that the amination was uncoupled from the deamination reaction by the electromagnetic activity of the mineral ions. The untreated Virginia peanut and several of the mineral-treated peanuts $\left(\mathrm{N}+\mathrm{P}+\mathrm{K}+\mathrm{S}, \mathrm{NH}_{4} \mathrm{Cl}\right.$, 
Table 2. GDH deamination and amination activities, GOGAT activities, free amino acids profiles, and total protein contents of peanut seeds harvested from control and mineral salts-treated plots.

\begin{tabular}{|c|c|c|c|c|c|c|c|c|c|c|}
\hline & Control & $\mathbf{N}+\mathbf{P}+\mathbf{K}+\mathbf{S}$ & $\mathbf{P i}$ & $\mathbf{S}$ & $\mathbf{K}$ & $\mathbf{N}$ & $\mathbf{N}+\mathbf{S}$ & $\mathbf{P}+\mathbf{S}$ & $\mathbf{P}+\mathbf{K}$ & $\mathbf{P}+\mathbf{N}$ \\
\hline GDH Deamination" & 12.2 & 18.6 & 10.7 & 1.38 & 5.5 & 12.4 & 11.2 & 8.5 & 0.7 & 12.9 \\
\hline GDH Animation & 0.6 & 11.6 & 16.9 & 14.1 & 9.5 & 12.0 & 10.1 & 10.4 & 39.6 & 17.8 \\
\hline Cellulose $^{\mathrm{c}}$ & 176.7 & 146.1 & 205.7 & 208.3 & 198.0 & 222.0 & 117.4 & 204.0 & 350.9 & 259.3 \\
\hline Protein ${ }^{\nu}$ & 335.0 & 322.0 & 500.0 & 545.0 & 595.0 & 584.0 & 339.0 & 515.0 & 910.8 & 605.0 \\
\hline Aminating Capacity & 0.05 & 0.6 & 1.6 & 10.1 & 1.7 & 1.0 & 0.9 & 1.2 & 61.0 & 1.4 \\
\hline${\text { GOGAT } \mathrm{K}_{\mathrm{m}}}^{*}$ & 1.0 & 0.8 & 5.0 & 0.9 & 1.25 & 0.58 & 0.34 & 1.0 & 0.84 & 1.25 \\
\hline GOGAT $\mathrm{V}_{\max }^{\dagger}$ & 0.83 & 0.71 & 0.83 & 0.83 & 0.83 & 0.71 & 0.53 & 1.25 & 0.33 & 0.83 \\
\hline $\mathrm{ASP}^{*}$ & 14.62 & 68.51 & 85.86 & 113.03 & 8.18 & 58.43 & 18.03 & 18.76 & 78.97 & 17.34 \\
\hline $\mathrm{Glu}^{*}$ & 145.15 & 265.82 & 247.28 & 228.56 & 180.40 & 156.04 & 172.60 & 237.33 & 199.41 & 203.17 \\
\hline Ser $^{*}$ & 36.98 & 79.26 & 57.68 & 64.07 & 33.16 & 35.92 & 47.72 & 88.22 & 37.47 & 37.31 \\
\hline Gly $^{*}$ & 18.05 & 42.86 & 56.09 & 61.03 & 13.43 & 34.05 & 25.50 & 40.81 & 58.40 & 18.62 \\
\hline His $^{*}$ & 49.09 & 149.31 & 192.39 & 284.21 & 28.95 & 131.77 & 34.41 & 90.91 & 204.38 & 45.74 \\
\hline $\operatorname{Arg}^{*}$ & 69.63 & 201.41 & 162.07 & 214.81 & 52.16 & 103.46 & 76.11 & 144.16 & 156.31 & 79.08 \\
\hline Thr $^{*}$ & 13.54 & 21.32 & 24.46 & 30.87 & 10.24 & 17.73 & 14.82 & 17.02 & 29.21 & 12.26 \\
\hline $\mathrm{Ala}^{*}$ & 22.29 & 35.84 & 65.84 & 85.38 & 15.24 & 43.96 & 28.69 & 45.84 & 55.53 & 20.76 \\
\hline Pro ${ }^{*}$ & 34.65 & 28.56 & 68.66 & 78.44 & 16.00 & 48.93 & 29.06 & 76.94 & 57.56 & 20.16 \\
\hline $\mathrm{Tyr}^{*}$ & 11.47 & 9.68 & 18.71 & 25.55 & 5.90 & 23.54 & 12.84 & 8.72 & 27.01 & 7.36 \\
\hline Lys $^{*}$ & $<0.2$ & $<0.2$ & $<0.2$ & $<0.2$ & $<0.2$ & $<0.2$ & $<0.2$ & $<0.2$ & $<0.2$ & $<0.2$ \\
\hline $\mathrm{Val}^{*}$ & 11.56 & 15.07 & 53.94 & 69.55 & 4.88 & 36.37 & 33.04 & 26.87 & 63.09 & 10.00 \\
\hline Met $^{*}$ & 5.58 & 12.16 & 29.36 & 28.24 & 4.16 & 15.31 & 11.67 & 13.70 & 16.44 & 3.85 \\
\hline $\mathrm{ILe}^{*}$ & 7.50 & 8.22 & 35.58 & 50.01 & 3.51 & 24.64 & 21.40 & 15.75 & 50.09 & 5.78 \\
\hline Leu $^{*}$ & 14.46 & 14.30 & 64.33 & 90.15 & 6.37 & 56.39 & 33.47 & 30.70 & 98.11 & 12.89 \\
\hline $\mathrm{Phe}^{*}$ & 34.09 & 25.69 & 54.23 & 44.90 & 18.68 & 44.49 & 52.24 & 25.95 & 49.87 & 22.81 \\
\hline $\operatorname{Tyr}^{*}$ & 21.00 & 6.91 & 14.10 & 15.13 & 17.06 & 4.58 & 12.03 & 12.69 & 24.41 & 14.84 \\
\hline $\mathrm{AA}\left(\mathrm{Kg} \cdot \mathrm{ha}^{-1}\right)$ & 9.80 & 14.70 & 30.81 & 37.71 & 12.10 & 27.12 & 11.99 & 22.14 & 52.39 & 16.64 \\
\hline GDH-a & $<1.0$ & 4.90 & 21.01 & 27.91 & 2.30 & 17.32 & 2.19 & 12.34 & 42.59 & 6.84 \\
\hline GDH-d & - & 8.17 & 13.13 & 2.73 & 1.35 & 16.76 & 2.43 & 10.09 & 0.75 & 5.0 \\
\hline
\end{tabular}

${ }^{9} \mathrm{GDH}$ deamination or amination is $\mu \mathrm{g}$ RNA $\mu \mathrm{g}^{-1} \mathrm{GDH}$ under the assay conditions described. Each is the average of 3 determinations from 3 different purifications of GDH. The error values were under $10 \%$ of the averages. "Amino acids are $\mathrm{mg} / 100 \mathrm{~g}$ of seeds. ${ }^{\star} \mathrm{GOGAT}$ apparent $\mathrm{k}_{\mathrm{m}}$ value for $\alpha$-KG is $\mu \mathrm{M}$. ${ }^{\dagger} \mathrm{GOGAT}$ $\mathrm{V}_{\max }$ is $\mu$ moles $\mathrm{min}^{-1} \mathrm{mg}^{-1}$ protein. ${ }^{\mathrm{c}}$ Seed lignocelluloses $\mathrm{Kg} \cdot \mathrm{ha}^{-1}$; GDH-a Kg amino acid aminated via GDH ha ${ }^{-1}$; GDH-d Kg amino acids deaminated by GDH $\mathrm{ha}^{-1} ;{ }^{\mathbf{v}} \mathrm{kg}$ seed protein ha ${ }^{-1}$.

$\mathrm{N}+\mathrm{S}$ ) induced GDH amination-deamination ratios of $<1.0$ (Table 2). This was also similar to the response of Valencia peanuts [13]. These suggest that in marginal and harsh environments (irregular rain fall, soil erosion, low soil organic carbon content, extreme temperatures, inadequate solar radiation, limited fertilizer supply etc) in which a few crop species are made to grow, plant GDHs could demonstrate some deamination molecular reaction mode $[2,7,19]$. GDH aminating capacity was very low in the control peanut (Table 2). The GDH aminating capacity of the $\mathrm{N}+\mathrm{K}+\mathrm{P}+\mathrm{S}$-treated peanut (the one closest to the control) was ten times higher than the control (Table 2). Was the GDH molecular aminating activity virtually silent in the control peanut? Several of the treated crops $(\mathrm{P}+\mathrm{S}, \mathrm{P}+\mathrm{N}, \mathrm{Pi}, \mathrm{K}$ etc) were intermediate with their GDH amination capacity between 1.0 
and 2.0 (Table 2). The GDHs of the S-treated, and especially the $\mathrm{P}+\mathrm{K}$-treated peanut had unequivocally high amination capacities. Was the GDH molecular deamination activity virtually silent in the $\mathrm{P}+\mathrm{K}$-treated peanut? Therefore, GDH activity was moved by the stoichiometric mineral salt combinations from the extreme left where it was molecularly deaminating to the extreme right where it was mainly aminating (Table 2). This demonstrated the broad-based environment-wide chemical span of the project. These results are in agreement with published biochemical results that prove GDH is aminating [3-5,20-23]. Many conversations on the biological role of the enzyme had focused narrowly on limited environmental conditions for plant growth, carbon and mineral starvation of the experimental plant specimens, and induction of protein catabolism thereby producing conclusions that supported only the deamination metabolic molecular mode without a reference aminating control mode.

The treatment of plants with electromagnetic combinations of mineral salts and assays of the RNA synthetic activity (Table 2) have thus advanced the knowledge on the biological chemistry of GDH by illuminating for the first time the wide range of possibilities and the complexity in the aminating activity due to the dependence of the isomerization on the management and environment of the crop. GDH is a multiple molecular enzyme. Therefore any conversation on its natural role must demonstrate the range of responses of the molecular forms to the environments under study.

Lignocellulose contents: Where the aminating capacities were $<1.0$ (control, $\mathrm{N}+\mathrm{K}+\mathrm{P}+\mathrm{S}-, \mathrm{N}+\mathrm{S}$-treated), the seed lignocellulose yields (Table 2) were also lowest $\left(117-176 \mathrm{~kg} \cdot \mathrm{ha}^{-1}\right)$. The lignocellulose yields increased $\left(200\right.$ - $\left.260 \mathrm{~kg} \cdot \mathrm{ha}^{-1}\right)$ through the $\mathrm{K}-, \mathrm{P}+\mathrm{S}-, \mathrm{Pi}-, \mathrm{N}-$, $\mathrm{S}$-treated etc peanuts with aminating capacities between 1.0 and 10.0 until at the $\mathrm{P}+\mathrm{K}$-treated peanut which had a very high aminating capacity of 61 and a very high lignocellulose yield of $351 \mathrm{~kg} \cdot \mathrm{ha}^{-1}$. Peanut GDH aminating capacities and seed lignocellulose yields followed similar trends as the shoot lignocellulose yields [24], fatty acid and seed yields [10]. If the natural role of GDH were deamination of glutamate, there would have been an inverse relationship between GDH aminating capacity and crop cellulose yield. Seed yield of the control peanut was within the normal yields by peanut farmers [25]. Therefore the peanuts were not starved of mineral and carbon nutrition.

Amino acid yield: The proximate free amino acid compositions of seed (Table 2) show that most amino acids were at least doubled in concentration in the S-, and $\mathrm{P}+\mathrm{K}$-treated peanuts compared with the control in agreement with the high amination-deamination ratio of the GDH of $\mathrm{S}-$, and $\mathrm{P}+\mathrm{K}$-treated peanuts and the low amination-deamination ratio of the control peanut. The free amino acid yields increased $\left(12.0-23.0 \mathrm{~kg} \cdot \mathrm{ha}^{-1}\right)$ through the $\mathrm{K}-, \mathrm{N}+\mathrm{K}+\mathrm{P}+\mathrm{S}-, \mathrm{Pi}-, \mathrm{N}+\mathrm{S}$-etc treated peanuts with aminating capacities between 1.0 and 2.0 until at the $\mathrm{P}+\mathrm{K}$-treated peanut which had a very high aminating capacity of 61 and a high amino acid yield of 52.4 $\mathrm{kg} \cdot \mathrm{ha}^{-1}$. Peanut free amino acids followed the trends of seed and shoot lignocellulose yields [24], fatty acid and seed yields [10]. Assimilation of $\mathrm{NH}_{4}^{+}$ion and $\alpha-\mathrm{KG}$ by GDH results to glutamate synthesis, the gate- way to the metabolism of most of the other amino acids. The correspondence of the trends of the amino acid yields, GDH aminating capacity and cellulose yields suggest that the natural role of GDH was the assimilation of $\mathrm{NH}_{4}^{+}$ion and $\alpha-\mathrm{KG}$, but not depletion of the gluta- mate pool by deaminating it to $\alpha-\mathrm{KG}$ in the treated pea- nuts. If $\mathrm{GDH}$ had been deaminating [7], the amination relationship with free amino acid yields would have been inverted.

Protein yield: In the untreated peanut, $\mathrm{N}+\mathrm{P}+\mathrm{K}+\mathrm{S}-$, $\mathrm{N}+$ S-treated etc peanuts (Table 2) where the GDH amination-deamination ratios were very low $(<1.0)$, and the free amino acid yields were low $\left(<26.0 \mathrm{~kg} \cdot \mathrm{ha}^{-1}\right)$, the protein yields were also low $\left(\sim 500.0 \mathrm{~kg} \cdot \mathrm{ha}^{-1}\right)$. Then the protein yields increased $\left(500-600 \mathrm{~kg} \cdot \mathrm{ha}^{-1}\right)$ through the $\mathrm{K}-, \mathrm{P}+\mathrm{S}-, \mathrm{Pi}-, \mathrm{N}$-treated etc peanuts with aminating capacities between 1.0 and 10.0 until at the $\mathrm{P}+\mathrm{K}$-treated peanut which had the highest aminating capacity and the highest protein yield of $910 \mathrm{~kg} \cdot \mathrm{ha}^{-1}$. The trend of peanut protein yields followed similar trends as the seed lignocellulose yields, shoot lignocellulose yields [24], fatty acid and seed yields [10]. If the enzyme had a deaminating natural role [7], the relationships between $\mathrm{GDH}$ amination capacity, cellulose and protein yields would have been inverted. Peanut protein contents are from $17 \%-25 \%$ [26], therefore, the control peanut's protein content was normal without protein catabolism that could have induced major deamination of glutamate to $\alpha-\mathrm{KG}$.

NADH-GOGAT activity: The $\mathrm{Km}$ and $\mathrm{V}_{\max }$ values (Table 2) of GOGAT were within the normal range [14] thus showing that the stoichiometric mineral salt combinations neither inhibited nor activated the enzyme. Therefore, the GS-GOGAT pathway functioned normally in the wide concentration variations (Table 1) of mineral ions as in the untreated control. This permitted the exclusion of methionine sulphoximine treatment [27] from the project. Only the GOGAT of the Pi-treated peanut had a high $\mathrm{Km}$ value $(5.0 \mathrm{mM} \alpha \mathrm{KG})$ suggesting very low activity of the enzyme. This could be related to the down-regulation of the mRNA encoding the enzyme by the GDH-synthesized RNA in the Pi-treated crop [12].

The natural role of GDH: The free amino acid yields and the GDH amination capacity enabled estimations of 
the quantities of $\mathrm{NH}_{4}^{+}$ion assimilation and of glutamate deamination by GDH. The normal GOGAT activity, taken together with the high deamination reaction mode of the GDH of the control peanut suggest that GSGOGAT cycle played a major role in the assimilation of $\mathrm{NH}_{4}^{+}$ion and $\alpha-\mathrm{KG}$ in the control peanut (Table 2). Using the free amino acid yield as the index for the total $\mathrm{NH}_{4}^{+}$ion assimilated, the free amino acid yield of 9.8 $\mathrm{kg} \cdot \mathrm{ha}^{-1}$ for the control peanut could be attributed to the activity of the GS-GOGAT cycle since the GDH amination activity was virtually silent in the treatment and could not make a substantial contribution to the production of glutamate. Furthermore, the high deamination activity of the GDH of the control peanut could have eroded some of the glutamate by deaminating it to $\alpha-\mathrm{KG}$ although aspartate amino transferase and glutamate decarboxylase also degrade glutamate even more efficiently [3]. Therefore, the adjusted total free amino acid should be slightly higher than 9.8, but for the purpose of estimating the quantity of amination it was assumed that GS-GOGAT accounted for all the $\mathrm{NH}_{4}^{+}$ion assimilation of the control peanut. Mineral treatment of the peanut increased the GDH amination activity but decreased the deamination activity with corresponding increases in the free amino acid yields (Table 2). Since GOGAT activity remained constant throughout the peanuts, the mineral nutrient-induced increases in free amino acid yields were attributable to GDH amination activity, the higher the GDH amination capacity the lower the quantity of glutamate lost via GDH deamination function etc.

In the $\mathrm{N}+\mathrm{P}+\mathrm{K}+\mathrm{S}$-treated peanut with $14.7 \mathrm{~kg} \cdot \mathrm{ha}^{-1}$ of free amino acids (Table 2), the quantity of amino acids resulting from amination by GDH was $4.9 \mathrm{~kg} \cdot \mathrm{ha}^{-1}$ by subtraction of the free amino acids $\left(9.8 \mathrm{~kg} \cdot \mathrm{ha}^{-1}\right)$ due from amination by GS-GOGAT cycle. The amination capacity (0.6) of the GDH of the $\mathrm{N}+\mathrm{K}+\mathrm{P}+\mathrm{S}$-treated peanut permits the calculation of the possible quantity of free amino acids $\left(8.17 \mathrm{~kg} \cdot \mathrm{ha}^{-1}\right)$ lost as $\mathrm{NH}_{4}^{+}$ion due to the deamination function of GDH etc. In the P+K-treated peanut with $52.39 \mathrm{~kg} \cdot \mathrm{ha}^{-1}$ of free amino acid yield (Table 2), the quantity of amino acids resulting from amination by GDH was $42.59 \mathrm{~kg} \cdot \mathrm{ha}^{-1}$ by subtraction of the free amino acids $\left(9.8 \mathrm{~kg} \cdot \mathrm{ha}^{-1}\right)$ due from amination by GS-GOGAT cycle. The amination capacity (61) of the $\mathrm{GDH}$ of the $\mathrm{P}+\mathrm{K}$-treated peanut permits the calculation of the quantity of amino acids $\left(0.75 \mathrm{~kg} \cdot \mathrm{ha}^{-1}\right)$ lost as $\mathrm{NH}_{4}^{+}$ion due to the possible deamination function of GDH. Similarly, the quantities of amino acids lost as $\mathrm{NH}_{4}^{+}$ion from the other peanuts as a result of the possible deamination function of GDH was estimated (Table 2). In the literature, previous estimates of the GDH deamination role were expressed superficially as activity per unit weight of protein. The RNA synthetic activity of GDH was different because it advanced far beyond the proximate level to permit the estimation of the possible quantities of amino acids eroded by the enzyme's deaminating activity per unit area of land. The results show that the natural role of the GDH deamination activity is to erode a fraction (Table 2) of the $\mathrm{NH}_{4}^{+}$ion assimilated by the enzyme; and the natural role of the GDH amination activity is to assimilate exponential multiples of the quantities of $\mathrm{NH}_{4}^{+}$ion as assimilated via the GS-GOGAT cycle. Therefore, the amination capacity of GDH is the quantitative statement of the amination efficiency of the enzyme. Stability of GOGAT over wide variations of mineral ion concentrations and compositions (Table 1) is evidence for the role of the GS-GOGAT cycle as the housekeeping machine for the salvage of $\mathrm{NH}_{4}^{+}$ion and $\alpha-\mathrm{KG}$. On the other hand, because GDH amination capacity increased in response to differentiating concentrations and compositions of mineral ions, it is the responsive mechanism for largescale assimilation of $\mathrm{NH}_{4}^{+}$ion and $\alpha-\mathrm{KG}$ (amination) that kicks into action under favorable growth conditions for crops. The coincidence in parallel of the trends of GDH amination-deamination ratios, free amino acids, total protein, fatty acids and peanut yields are strong evidence that the crop yield doubling biotechnology [12] is the collateral chemical support on which the aminating role of GDH stands. Labeling of $\mathrm{NH}_{4}^{+}$ion or glutamate and computational simulations [9] of amino acid flux did not illuminate the natural role of GDH probably because among other kinetics considerations, the rapidly reversible oxidoreductase reaction embodies a substantial incompleteness in the relative quantities of reaction products estimated. The assay of the RNA products instead is more complete because the RNA synthesized is stable, not hydrolyzed by GDH.

\section{DISCUSSION}

Synthesis of RNA by hexameric GDH isoenzymes is an integral chemical property of the enzyme [28]. The functions of GDH-synthesized RNA have illuminated several hitherto inexplicable biological phenomena including the detoxification of xenobiotics by plants [1], permutation of the primary metabolic pathways at the mRNA level [12], the evolutionary adaptation of metabolism to wide variations of the concentrations and compositions of the mineral nutrient environment [10], regulation of fatty acid contents by lipoxygenase [29], regulation of the oleic acid/linoleic acid ratios, and elimination of allergenic arachins $[10,12,24]$. Therefore, RNA synthesis is appropriate biochemical reaction for evaluating the activity of GDH $[11,30]$. Results in Figures 1 and 2, $[10,12]$ are the first time that large quantities of non-genomic RNAs are being subjected side-by-side with genomic RNA to rigorous molecular biology pro- 
cedures. The free solution isoelectric focusing purification produced 8 - 11 preparations of GDH instead of one per treated peanut. The whole-gel purification produced 12 fractions of pure GDH isoenzymes per treated peanut, each fraction of which was used for RNA synthesis in the deaminating then in the aminating direction. Therefore, there were 12 replicate purifications of GDH, and 12 replicate synthesis of RNA in each reaction direction per treated peanut. The results (Figures 1 and 2) demonstrate excellent reproducibility and repeatability in liquid handling and electrophoretic operations, and reliability of the chemistry of the reactions. The vivid differences between the GDH-synthesized RNA and genomic RNA are additional quality assurance characteristics of the GDH-synthesized RNA in conformation with the biological chemistry of the nucleic acids.

The possible quantities of $\alpha$-KG produced via deamination of glutamate by GDH (Table 2) per treated peanut were miniscule compared with the large $\mathrm{kg}$ quantities of acetyl CoA and glycolytic pathway intermediates that are required for synthesis of $\mathrm{kg}$ quantities of fatty acids and carbohydrates in peanut [12]. This project did not investigate the metabolic urgency that could necessitate the possible conversion of glutamate to $\alpha-\mathrm{KG}$ by GDH. However, the supply of large quantities of $\alpha-\mathrm{KG}$ and other Krebs (citric acid) cycle intermediates in peanut is controlled by inorganic phosphate translocator, granulebound starch synthase, and phosphoglucomutase (PGM) for intermediary metabolism, fatty acid and cellulose biosyntheses both in the deficit and favorable environmental conditions; the different accumulation of fatty acid and cellulose being caused by the activities of acetyl CoA carboxylase (ACCase) and glucosyltransferase [12]. There were no indications $[10,12,13]$ that the very high deaminating activities of the GDHs of the control, Pi-, $\mathrm{NH}_{4} \mathrm{Cl}-$ and $\mathrm{N}+\mathrm{P}+\mathrm{K}+\mathrm{S}$-treated peanuts caused elevated Krebs cycle metabolism and/or of protein catabolism. Carbon dioxide assimilation is regulated in peanut [12] by $\mathrm{Pi}$ translocator, a chloroplast membrane protein antiport system that uses $\mathrm{Pi}$ and phosphorylated $\mathrm{C} 3, \mathrm{C} 5$, or C6 compounds as counter substrates [31]. Granulebound starch synthase (GBSS) is another point for regulation of $\mathrm{CO}_{2}$ assimilation in peanut. It catalyzes the formation of $\alpha-(1-4)$-linked linear glucosyl chains [32]. Phosphoglucomutase (PGM) is a regulatory step in peanut glycolysis. It proportions carbon between the pathways of starch synthesis and glycolysis [33]. Glucosyltransferase regulates peanut saccharide metabolism [13]. Cellulose biosynthesis involves chain initiation, elongation and termination, with the participation of glucosyltransferase in the chain initiation reaction [34]. ACCase catalyzes the ATP-dependent carboxylation of acetyl-CoA to form malonyl-CoA, the precursor for fatty acid synthesis [10-12]. ACCase controls the production of fatty acids in peanut [10]. Messenger RNAs encoding the regulatory enzymes listed above are fully or partially down-regulated via spatial permutation by their homologous GDH-synthesized RNAs. Therefore, these results together with the normal steady activity of GOGAT (Table 2) suggest that the supply of $\alpha-K G$ for Krebs cycle metabolism is not via protein degradation and the GDH deamination of glutamate [35]. In view of the miniscule quantities of $\alpha-\mathrm{KG}$ possibly produced by GDH deamination activity, the deamination mode of GDH may be a kinetic metabolic state that enables the enzyme to synthesize RNAs (Figure 1) for down regulating and coordinating the mRNAs encoding phosphate translocator, GBSS, PGM, GARS/GART etc to assure that carbon and nitrogen metabolism are not shut down simultaneously $[10,12]$ when the crop is growing in deficit environments. The parallel coincidence of the trends of GDH amination-deamination ratios, free amino acids yields, cellulose, fatty acids and total protein yields with peanut yield are strong evidence that the crop yield doubling permutation of the metabolic pathways at the mRNA level by GDH-synthesized RNA $[12,13,24]$ is the collateral chemical support for the aminating role of GDH.

The economic importance of the GDH aminating activity (Table 2) in crop production may be deduced by comparing the total protein, and pod yields of the untreated, $\mathrm{N}+\mathrm{P}+\mathrm{K}+\mathrm{S}$ (similar to commercial fertilizer), and $\mathrm{P}+\mathrm{K}$-treated peanuts. The protein and pod yields of the $\mathrm{P}+\mathrm{K}$-treated peanut were at least double those of the $\mathrm{N}+\mathrm{P}+\mathrm{K}+\mathrm{S}$, and untreated peanuts which were the normal yields from farmers' plots [25]. The doubling of protein yield by maximizing the GDH aminating activity is a positive litmus test in support of the natural role of the enzyme. There is need to maximize and double crop protein yields per unit area of land in order to feed a malnourished population of infants, mothers, and children in some of the developing zones of the world that are deficient in animal/fish protein-rich diets [36,37]. If staple food crops were to double and escalate their protein yields simply by maximizing their GDH aminating activity, without increasing the cultivated land area, without increasing fertilizer and water applied, without increasing man-hour input, substantial plant proteins to meet part of the protein turnover needs of kwashiorkor children could be locally obtained by the developing nations.

\section{REFERENCES}

[1] Osuji, G.O., Brown, T.K. and South, S.M. (2008) Discovery of the RNA synthetic activity of glutamate dehydrogenase and its application in drug metabolism research. The Open Drug Metabolism Research, 2, 1-13. 


\section{doi:10.2174/1874073100802010001}

[2] Robinson, S.A., Slade, A.P., Fox, G.G., Phillips, R., Ratcliffe, R.G. and Stewart, G.R. (1991) The role of glutamate dehydrogenase in plant nitrogen metabolism. Plant Physiology, 95, 509-516. doi:10.1104/pp.95.2.509

[3] Oaks, A. (1994) Primary nitrogen assimilation in higher plants and its regulation. Canadian Journal of Botany, 72, 739-750. doi:10.1139/b94-094

[4] Melo-Oliveira, R., Oliveira, I.C. and Coruzzi, G. (1996) Arabidopsis mutant analysis and gene regulation define a nonredundant role for glutamate dehydrogenase in nitrogen assimilation. Proceedings of the National Academy of Sciences, 93, 4718-4723. doi:10.1073/pnas.93.10.4718

[5] Osuji, G.O. and Braithwaite, C. (1999) Signaling by glutamate dehydrogenase in response to pesticide treatment and nitrogen fertilization of peanut. Journal Agricultural Food Chemistry, 47, 3332-3344. doi:10.1021/jf9805303

[6] Lea, P.J. and Miflin, B.J. (1974) Alternative route for nitrogen assimilation in higher plants. Nature, 251, 614616. doi:10.1038/251614a0

[7] Robinson, S.A., Stewart, G.R. and Phillips, R. (1992) Regulation of glutamate dehydrogenase activity in relation to carbon limitation and protein catabolism in carrot cell suspension cultures. Plant Physiology, 98, 11901195. doi:10.1104/pp.98.3.1190

[8] Yamaya, T., Oaks, A. and Matsumoto, H. (1984) Characteristics of glutamate dehydrogenase in mitochondria prepared from corn shoots. Plant Physiology, 76, 10091013. doi:10.1104/pp.76.4.1009

[9] Rhodes, D., Brunk, D.G. and Magalhaes, J.R. (1989) Assimilation of ammonia by glutamate dehydrogenase? In: Poulton, J.E., Romeo, J.T. and Conn, E.E., Eds., Recent advances in Phytochemistry, Plant Nitrogen Metabolism, 23, Chapter 6, Plenum Press, New York and London.

[10] Osuji, G.O., Brown, T.K., South, S.M., Johnson, D. and Hyllam, S. (2012) Molecular modeling of metabolism for allergen-free low linoleic acid peanuts. Applied Biochemistry and Biotechnology, 168, 805-823. doi:10.1007/s12010-012-9821-6

[11] Osuji, G.O., Konan, J. and M'Mbijjewe, G. (2004) RNA synthetic activity of glutamate dehydrogenase. Applied Biochemistry and Biotechnology, 119, 209-228. doi:10.1007/s12010-004-0003-Z

[12] Osuji, G.O., Brown, T.K., South, S.M., Duncan, J.C. and Johnson, D. (2011) Doubling of crop yield through permutation of metabolic pathways. Advances in Bioscience and Biotechnology, 2, 364-379. doi:10.4236/abb.2011.25054

[13] Osuji, G.O., Brown, T.K. and South, S.M. (2010) Optimized fat and cellulosic biomass accumulation in peanut through biotechnology. International Journal of Biotechnology \& Biochemistry, 3, 455-476.

[14] Lea, P.J., Blackwell, R.D., Chen, F. and Hecth, U. (1990) Enzymes of ammonia assimilation. In: Dey, P. and Harborne, J., Eds., Methods in Plant Biochemistry: Enzymes of Primary Metabolism, Vol. 3, Chapter 15, Academic Press, New York.
[15] Osuji, G.O., Cuero, R.G. and Washington, A.C. (1991) Effects of $\alpha$-ketoglutarate on the activities of the glutamate synthase, glutamate dehydrogenase, and aspartate transaminase of sweet potato, yam tuber, and cream pea. Journal Agricultural and Food Chemistry, 39, 1590-1596. doi:10.1021/jf00009a010

[16] Osuji, G.O. and Madu, W.C. (1995) Ammonium iondependent isomerization of glutamate dehydrogenase in relation to glutamate synthesis in maize. Phytochemistry, 39, 495-503. doi:10.1016/0031-9422(94)00976-Z

[17] Skopelitis, D., Paranychiantis, N., Kouvarakis, A., Sypros, A., Stephenou, E. and Rubenakis-Angelakis, K. (2007) The isoenzyme 7 of tobacco NADH-dependent glutamate dehydrogenase exhibits high deamination and low aminating activity. Plant Physiology, 145, 1726-1734. doi:10.1104/pp.107.107813

[18] Cammaerts, D. and Jacobs, M. (1983) A study of the polymorphism and the genetic control of glutamate dehydrogenase isoenzymes in Arabidopsis thaliana. Plant Science Letters, 31, 67-73. doi:10.1016/0304-4211(83)90130-X

[19] Lea, P.J. and Miflin, B.J. (2003) Glutamate synthase and the synthesis of glutamate in plants. Plant Physiology and Biochemistry, 41, 555-564. doi:10.1016/S0981-9428(03)00060-3

[20] Britton, K.L., Baker, P.J., Rice, D.W. and Stillman, T.J. (1992) Structural relationship between the hexameric and tetrameric family of glutamate dehydrogenases. European Journal of Biochemistry, 209, 851-859. doi:10.1111/j.1432-1033.1992.tb17357.x

[21] Osuji, G.O., Braithwaite, C., Pointer, R. and Reyes, J. (1999) Pesticide inactivation of peanut glutamate dehydrogenase: Biochemical basis of the enzyme's isomerization. Journal of Agricultural and Food Chemistry, 47, 3345-3351. doi:10.1021/jf980531v

[22] Lehmann, T. and Ratajczak, L. (2008) The pivotal role of glutamate dehydrogenase (GDH) in the mobilization of $\mathrm{N}$ and $\mathrm{C}$ from storage material to asparagines in germinating seeds of yellow lupin. Journal of Plant Physiology, 165, 149-158. doi:10.1016/j.jplph.2006.12.010

[23] Dubois, F., Terce-Laforgue, T., Gonzalez-Moro, M., Estavillo, J., Sangwan, R., Gallais, A. and Hirel, B. (2003) Glutamate dehydrogenase in plants: Is there a new story for an old enzyme? Plant Physiology and Biochemistry, 41, 565-576. doi:10.1016/S0981-9428(03)00075-5

[24] Osuji, G.O., Brown, T.K., South, S.M., Duncan, J.C., Johnson, D. and Hyllam, S. (2012) Molecular adaptation of peanut metabolic pathways to wide variations of mineral ion composition and concentration. American Journal of Plant Sciences, 3, 33-50. doi:10.4236/ajps.2012.31003

[25] Pease, J., Bullen, G., Roberts, M. and Shokes, F. (2012) National Peanut Board. In Economic Impacts of the 2002 Farm Bill on Peanut Farms in Six States. http://www.nationalpeanutboard.org/growers_details.php ?rsID $=368$

[26] Fageria, N.K., Baligar, V.C. and Jones, C. (1997) Growth and mineral nutrition of field crops. 2nd Edition, Marcel Dekker, Inc., New York, 494. 
[27] Osuji, G.O. and Madu, W.C. (1997) Regulation of peanut glutamate dehydrogenase by methionine sulphoximine. Phytochemistry, 46, 817-825. doi:10.1016/S0031-9422(97)00395-6

[28] Osuji, G.O., Braithwaite, C., Fordjour, K., Madu, W.C., Beyene, A., Roberts, P.S. and Wright, V. (2003) Purification of glutamate dehydrogenase isoenzymes and characterization of their substrate specificities. Preparative Biochemistry and Biotechnology, 33, 13-28. doi:10.1081/PB-120018366

[29] Osuji, G.O., Brown, T.K. and South, S.M. (2009) Nucleotide-dependent reprogramming of mRNAs encoding acetyl coenzyme A carboxylase and lipoxygenase in relation to the fat contents of peanut. Journal of Botany, 2009, 278324. doi: $10.1155 / 2009 / 278324$

[30] Osuji, G.O., Haby, V.A. and Chessman, D.J. (2006). Metabolic responses induced by serial harvesting of alfalfa Pasteur established on amended acid soil. Communications in Soil Science and Plant Analysis, 37, 12811301. doi:10.1080/00103620600623608

[31] Knappe, S., Flugge, U. and Fischer, K. (2003) Analysis of the plastidic phosphate translocator gene family in Arabidopsis and identification of new phosphate translocator-homologous transporters, classified by their putative substrate-binding site. Plant Physiology, 131, 11781190. doi:10.1104/pp.016519

[32] James, M.G., Denyer, K. and Myers, A.M. (2003) Starch synthesis in the cereal endosperm. Current Opinion in Plant Biology, 6, 215-222. doi:10.1016/S1369-5266(03)00042-6
[33] Davis, E.J., Tetlow, I.J., Bowsher, C.G. and Emes, M.J. (2003) Molecular and biochemical characterization of cytosolic phosphoglucomutase in wheat endosperm. Journal Experimental Botany, 54, 1351-1360. doi:10.1093/jxb/erg151

[34] Saxena, I.M. and Brown, R.M. (1977) Identification of cellulose synthases in higher plants: Sequence analysis of processive $\beta$-glycosyltransferases with the common motif 'D, D, D35Q(R,Q)XRW'. Cellulose, 4, 33-49. doi:10.1023/A:1018411101036

[35] Miyashita, Y. and Good, A.G. (2008) Glutamate deamination by glutamate dehydrogenase plays a central role in amino acid catabolism in plants. Plant Signal and Behavior, 3, 842-843. doi:10.4161/psb.3.10.5936

[36] Okwu, G.N., Ukoha, A.L., Nwachukwu, N. and Agha, N.C. (2007) Studies on the predisposing factors of protein-energy malnutrition among pregnant women in $\mathrm{Ni}$ gerian community. Online Journal Health Allied Sciences, 3, 1-9.

[37] Waterlow, J.C. (1994) Childhood malnutrition in developing nations: Looking back and looking forward. In: Olson, P.E., Bier, D.M. and McCormick D.B., Eds., Annual Review of Nutrition. Annual Review Inc., Palo Alto, 14, 1-19.

[38] Grierson, D., Slater, A., Speirs, J. and Tucker, G.A. (1985) The appearance of polygalacturonase mRNA in tomatoes: One of a series of changes in gene expression during development and ripening. Planta, 163, 263-271. doi:10.1007/BF00393517 